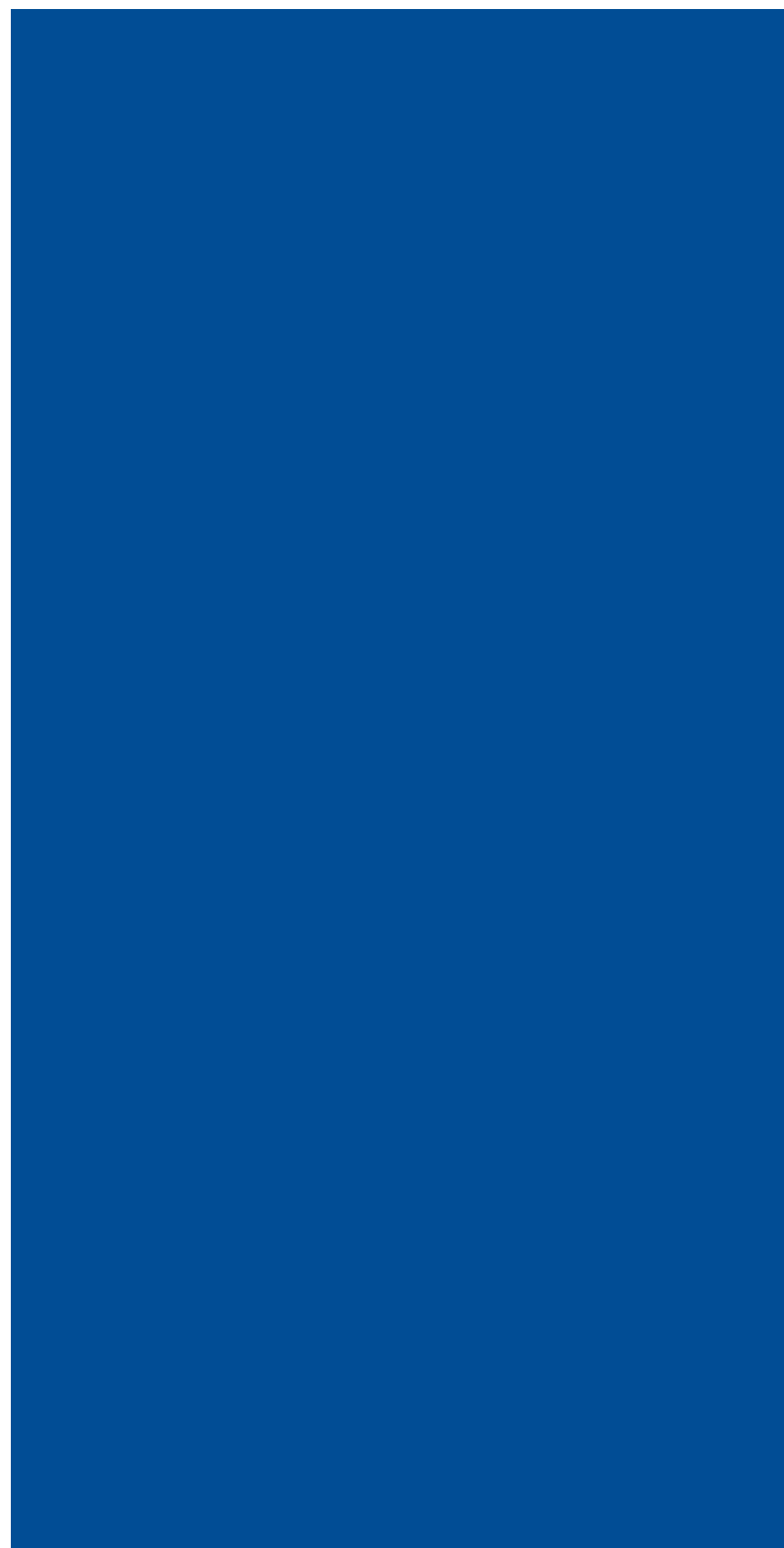

Volume 18, Number 3, 2008

Biological gerontology

The normal ageing kidney - morphology and physiology

J.-F. Macías Núñez

\title{
Clinical geriatrics
}

Bone health in stroke

M. J. Haddaway and M. W. J. Davie

How does age affect the success of total replacement of the hip joint? T. E. Cope

Prevention and treatment of venous thromboembolism in older people A. Veiraiah, H. G. M. Shetty and P. A. Routledge

Neuropsychiatry of old age

Visual attention-related processing in Alzheimer's disease

A. Tales and G. Porter

\section{CAMBRIDGE}




\section{Reviews in

\section{EDITOR}

Dr Antony Bayer, Department of Geriatric Medicine, Cardiff University, University Hospital Llandough

\section{SECTION EDITORS}

\section{Biological gerontology}

Professor Margot Gosney, Elderly Care Medicine, The

University of Reading

Clinical geriatrics

Dr Hilary Wynne, Freeman Hospital,

Newcastle upon Tyne

Neuropsychiatry of old age

Dr Antony Bayer, Department of Geriatric Medicine,

Cardiff University, University Hospital Llandough

Psychological and social gerontology

Dr Norman Vetter, Cardiff University (retired), Cardiff

Education and Training

Dr M. Hasan, Department of Geriatric Medicine, Cardiff

University, University Hospital Llandough

\section{EDITORIAL BOARD}

G. S. Alexopoulos, Cornell University Medical College, New York, USA

Gary Andrews, Flinders University of South Australia, Bedford Park, Australia

Elizabeth Barrett-Connor, University of California, San Diego, USA

Klaus Bergmann, The Maudsley Hospital, London, UK

Ruth Bonita, University of Auckland, Takapuna, New Zealand
Peter W. Burvill, University of Western Australia, Nedlands, Australia

John Campbell, University of Otago, Dunedin, New Zealand

Willi De Weerdt, Katholieke Universiteit, Leuven, Belgium

Sijmen Duursma, University of Utrecht, The Netherlands Shah Ebrahim, University of London, UK

Lars Gustafson, University of Lund, Sweden

Ronald C. Hamdy, East Tennessee State University,

Johnson City, USA

Rosalie Kane, University of Minnesota, Minneapolis, USA

Jeannie Kayser-Jones, University of California, San

Francisco, USA

Tom Kirkwood, Newcastle University, UK

Shigemi Kono, Reitaku University, Chiba-ken, Japan

Helena Leino-Kilpi, University of Turku, Finland

George M. Martin, University of Washington, USA

Walter Pelemans, University of Leuven, Belgium

Brice Pitt, University of London, UK

Peter V. Rabins, Johns Hopkins Medical Institutions,

Baltimore, USA

George S. Roth, National Institute on Aging, Bethesda, USA

Hok Maria Salczerne, Central Training Institute of

Qualified Health Workers, Budapest, Hungary

Gerdt Sundström, Institute for Gerontologi, Jonkoping,

Sweden

E. Idris Williams, University of Nottingham, UK

\section{EDITORIAL POLICY}

The majority of the articles are commissioned from recognized authorities. However, proffered papers will be considered for publication; these will be submitted for peer review. Correspondence is welcome, particularly concerning published reviews. Priority will be given to letters that are less than 250 words long and typed with double spacing. All authors should sign the letter. Correspondence should be addressed to Dr Antony Bayer, Editor, Reviews in Clinical Gerontology, Department of Geriatric Medicine, Cardiff University, 3rd Floor, Academic Centre, University Hospital Llandough, Penlan Road, Penarth CF64 2XX, UK.

\section{SUBSCRIPTIONS}

Reviews in Clinical Gerontology (ISSN 0959-2598) is published four times a year in February, May, August and November. Four parts form a volume. The subscription price (excluding VAT) of a volume, which includes print and electronic access is $£ 364.00$ (US $\$ 646.00$ in USA, Canada and Mexico); $£ 92.00$ (US \$175.00) for individuals, which includes print only, ordering direct from the publishers and certifying that the journal is for their personal use. The electronic-only price available to institutional subscribers is $£ 308.00$ (US $\$ 536.00$ in USA, Canada and Mexico). Single parts are $£ 98.00$ net (US \$162.00 in USA, Canada and Mexico) plus postage. EU subscribers (outside the UK) who are not registered for VAT should add VAT at their country's rate. VAT registered members should provide their VAT registration number. Japanese prices for institutions (including ASP delivery) are available from Kinokuniya Company Ltd, P.O. Box 55, Chitose, Tokyo 156, Japan. Back volumes are also available.

Orders, which must be accompanied by payment, may be sent to a bookseller, subscription agent or direct to the publisher: Cambridge University Press, The Edinburgh Building, Shaftesbury Road, Cambridge CB2 8RU, UK; or in the USA, Canada and Mexico: Cambridge University Press, Journals Fulfillment Department, 100 Brook Hill Drive, West Nyack, New York 10994-2133. EU subscribers (outside the UK) who are not registered for VAT should add VAT at their country's rate. VAT registered subscribers should provide their VAT registration number. Japanese prices for institutions are available from Kinokuniya Company Ltd, PO Box 55, Chitose, Tokyo 156, Japan.

Periodicals postage paid at New York, NY, and at additional mailing offices. POSTMASTER: send address changes the USA, Canada and Mexico to: Reviews in Clinical Gerontology, Cambridge University Press, 32 Avenue of the Americas, New York, NY $10013-2473$.

Claims for missing issues should be made immediately on receipt of the subsequent issue.

\section{ADVERTISING}

Apply to the publisher. Address enquiries to: Rebecca Curtis (UK) or the Advertising Co-ordinator (North America). 